\title{
The Transmission of Hatred and the Hatred of Transmission: The Psychopathology of a Murder and an Anatomy of a Silence. The Nobody's Name: A Contemporary Symptom
}

Was Du ererbt von Deinen Vätern hast, / Erwirb es, um es zu besitzen. J. W. von Goethe, Faust I.

\section{Abstract}

The aim of this paper is to address the psychopathology of antisemitism, antiJewish aggressions, and more specifically of present-day denials of the Real, a version of "negationism" or "denialism," which has always been consubstantial with it.

As a starting point, I will use two particularly savage murders, which were committed in France ten years apart (fifteen targeted attacks having taken place in the meantime). In 2007, a young man named Ilan Halimi, precariously employed as a sales assistant in a cell phone shop, was kidnapped as a Jew (hence supposedly likely to raise a huge ransom). He was tortured for twentyfour days and finally murdered, the persistent denial of the antisemitic nature of the act tragically hampering the conduct of the investigation. In May 2017, a sixty-seven-year-old Jewish woman employed at a kindergarten and living in a low-income Paris neighborhood was tortured for a whole night in her home by a twenty-seven-year-old man whose Muslim family, including himself, had been insulting and threatening her for months. She was finally murdered and thrown out of a window. Her name was Sarah Halimi. The anatomy of the act itself, as well as the resounding silencing of its antisemitic nature by intellectuals, politicians, and the media can truly be interpreted as a contemporary symptom.

I will be concerned here with exploring the mass-psychology characterizing antisemitism, together with the genealogy of the culture underlying it, which presents itself as a meeting point for Christian radicalism, the ultra-left, an expression of the return of a Paulinian repressed, and Islamic totalitarianism.

The parasemitic anti-Zionist obsession combined with an ideological desubstantialization of reality leads to a vicarious mob murder, whether its form be the so-called "lone wolf" kind or that of collective action. What operates in all cases 
is a compulsion to repeat and a perverse purifying all-absolving narcissistic guilt, the [resulting?] violence and destruction being helped by the "failures" of national, republican, and international authorities supposedly acting as guarantors for the symbolic order, as well as those of eroded and perverted structuring landmarks (the law, history, civilizing prohibitions and commandments).

In my view, Judeophobia can be seen as the expression of projections activated by a mortified sense of self, an identity-based hatred attempting to dissolve an underlying unconscious hatred by resorting to an object likely to legitimize it. This is achieved by attributing to the Jewish "Other" a power of "being" that can only be conceived metonymically in terms of "having," an entanglement of archaic envy, mimetic identification, and narcissistic omnipotence, together with a fantasy of substitution. A delirious conception of filiation or selfgeneration, the rejection of all indebtedness, of sexual and generational difference, of alterity and narcissistic incompleteness, a quest for immediate and limitless enjoyment, an investment of totality, possibly through destructiveness-all of this implies a rejection of the ethics of truth, of spiritual elevation, of the building-up of subjectivity, of a singularity conceived as a universal and of a responsible freedom. Simultaneously, it counter-invests transmission as a process, the transmission of transmission as an introduction to oedipal competition, the unknown, the field of fantasy and transference, the in-between space of ambivalence and indefinite thought.

These questions will finally serve as an introduction to another question: that of the building of a people. 


\section{Introduction: Making an Event of the Tragedy: Restoring a Face to Sarah Halimi}

The tragedy of Sarah Halimi's murder took place in spring 2017 and was immensely traumatic for the [French?] Jewish community, not only on account of the particularly savage and horrifying character of the act, but also-beyond the horror, and with equal significance-because of its treatment as insignificant by the media sphere as well as by politicians and intellectuals. Jews thus found themselves once again excluded from the inter-subjective sphere, at least until President Emmanuel Macron declared, in his speech commemorating the 1942 "Vel d'Hiv Roundup" of Paris Jews by French police prior to their deportation to the death camps, that he had given orders for justice to shed full light on the affair.

\section{A Clinical Study of Contemporary Reality}

A clinical study of contemporary reality cannot but perceive a paradigmatic symptom in the fact that the barbaric murder of Sarah Halimi in Paris and the ensuing resounding silence on the part of the prevailing "doxa" took place ten years after the murder of Ilan Halimi, appearing thus as a hallucinatory compulsion to repeat the desubstantializing denial of reality, ${ }^{1}$ of the antisemitic nature of Islamist crime, and of the group psychopathology (with culture here playing the part of a collective psyche), which binds, inhabits, and activates desingularized and atomized individuals, as Freud has demonstrated in Group Psychology and the Analysis of the Ego. ${ }^{2}$ This significant and genuine symptom can be seen as a Pavlovian reproduction.

How is it that no lesson was learnt from the police mistakes, constant bungling during the twenty-four-day abduction of Ilan Halimi, a young man kidnapped, tortured, and murdered in 2006 because he was a Jew, by the self-named "Gang of Barbarians." Ten years and a great many deaths later, ten years later, then, from one Halimi to another, from Ilan to Sarah, both savagely tortured, murdered, like the children in Toulouse killed in cold blood in front of their Jew-

1 Cf. M. G. Wolkowicz, ed., Le sujet face au réel, et dans la transmission (Paris: In Press, 2017).

2 Cf. S. Freud, Group Psychology and The Analysis of The Ego, in vol. 18 of The Standard Edition of the Complete Psychological Works of Sigmund Freud, ed. J. Strachey (London: The Hogarth Press and the Institute of Psycho-analysis, 1955). 
ish school, or like children in Israel: this is almost a textbook case for those who want to scrutinize the collective unconscious and its pathologies.

Sarah Halimi, too, had been subjected to antisemitic abuse on the part of the murderer's family, and her own children had had the same experience as victims and witnesses. Having first entered Sarah's next-door neighbors' apartment, the murderer climbed into her flat, where she lived alone, via the balcony and started beating her to death with horrendous, relentless savagery, shouting insults, and reciting suras from the Qur'an all the while. All this was heard and recorded by Sarah's neighbors, together with her desperate cries for help and screams of pain. Her face and body broken in twenty places, the dying woman was finally thrown out of a third-floor window, her corpse lying on the ground like something left over, a scrap, a bag, a piece of rubbish, a stück, a schmatteh. Incredibly enough, all this took place without any intervention from the three police officers who had been present in the building since four o'clock, and who had been called by the neighbors locked up by the murderer. While he was slaughtering her, Sarah's torturer kept calling her "Satan" in Arabic. In the end, having "finished off" his victim under the nose of the police, the murderer returned via the neighbors' apartment, still praying aloud, the human sacrifice over, and was peacefully arrested by the thirty or so police officers then present on the spot, twenty-seven of whom were members of a heavily armed elite squad sent as reinforcements. For reasons which have remained obscure to this day, none of them had intervened while the old woman was being tortured to death. The arrest was made at half past five in the morning. The man did not put up any resistance. As for Sarah, she was lying dead on the pavement.

Several dozens of neighbors never made a move. The national media were informed but did not investigate, and the murder was passed over in silence. Her name was Sarah-Sarah Halimi.

This atrocious scene did not take place in 1942, before or after the Vel'd'Hiv Roundup, but during the night from April 3 to April 4, 2017, to cries of "Allahu Akbar” located in a small apartment in a low-income block of flats. A white march organized the next Sunday in Belleville to honor her memory came up against shouts like "Death to Jews!” and "We've got our kalash!” on the part of youngsters from the neighboring housing estates. Without any loss of time, the public prosecutor hastened to explain that one would have to wait for the results of the enquiry before the murder could be characterized. Who knows? In case the savage murder of an old Jewish woman by a sturdy young Islamist with a long criminal record might fall within the category of neighborhood quarrels. Incidentally, the murderer, Kobili Traoré, of Malian origin, used to terrorize his victim and repeatedly called her a "dirty Jew." 


\section{A Deathly Silence}

“We are at war," Prime Minister Manuel Valls declared on January 13, 2015, so that Muslims may no longer "be ashamed" and "any Jews [...] be afraid any more." 3 A strange symmetry and a strange assessment in a country in which it has once again become possible to murder Jews without our compatriots being overly moved. A mere news item? Not even that. Antisemitism has an extraordinary capacity for adaptation; yesterday it was denouncing an excess of Jewish existence-Jews having too much, being too many, doing too much, just as Israel's defensive actions are always "disproportionate" and its name, too, is one too many; today the same applies to the negative hallucination turning Jews into mere ghosts. Bodies are run over on Nice's Promenade des Anglais and the catchphrase "living together [in harmony]" is flung over them like a shroud. Dozens of young people are shot down by Kalashnikovs at the Bataclan concert hall and the next morning in every trendy café glasses are clinked as a toast to "living together." Yet there are districts in France that the Jews have had to leave, because their kippas made them easy targets for aggression. Others, non-Jews, have followed suit. Only the poorest have remained. They cannot afford to go anywhere else and have no choice but to submit to "living together." Thus not a word was said during the French presidential election campaign, and most media remained silent. Just as the Nice mass murderer, Belleville's Jihadist was deemed "insane."

\section{This Kind of Denial ${ }^{5}$ Has already Killed in France}

Fifty-eight percent of the attacks carried out in France are directed against Jews, who represent $0.7 \%$ of the population. This should never be tolerated in a healthy democracy, and as everyone knows any resurgence of antisemitism has always been a sure touchstone for a society's moral and political state of

3 Cf. "Tribute to the Victims of the Attacks: Speech by M. Manuel Valls, Prime Minister, in the National Assembly," issued January 13, 2015, accessed January 8, 2021, https://www.gouverne ment.fr/en/tribute-to-the-victims-of-the-attacks.

4 P. Bruckner, "L’inversion de la dette. Antisémitisme et islamophobia," in Présence de la Shoah et d'Israël dans la pensée contemporaine: Nom sacré / Nom maudit, ed. M. G. Wolkowicz (Paris: In Press, 2014), 97.

5 Cf. S. Freud, The Loss of Reality in Neurosis and Psychosis, in vol. 19 of The Standard Edition of the Complete Psychological Works of Sigmund Freud, ed. J. Strachey (London: The Hogarth Press and the Institute of Psycho-analysis, 1961). 
health. Yet the authorized hatred and the uninhibited aggressions of some, together with the deliberate blindness and approval of others, in silence or in joy, stare us in the face. And last but not least, there is the tragic "beautiful" indifference of the vast mainstream indifference.

This event-an antisemitic murder coupled with a denial of its antisemitic character-caused a real trauma in the French Jewish community, since it combined the obliteration of the victim's Jewishness with the automatic dismissal of the murderer's responsibility-the criminal being promptly declared "mentally ill" to prevent any link being established between this attack and terrorism, between terrorism and the war that is being waged against us, between Jihad and Islamism (an impressive number of children in France have been given the first name "Jihad" in the last few years), between Islamism and Islam, and lastly between the Palestinian genocidal terrorism against Israel and the Israelis, and the murderous terrorism in Europe. Equally significant was the fact that the tragedy of this particularly brutal and barbaric murder had been predictable and inscribed itself in a long list of similar acts eliciting little response from the authorities, a series of attacks and mass murders directed against the population with the aim of terrorizing people and deterring them from living and thinking freely but also of controlling the whole Muslim population as well as the "norights zones" (i.e., no Republican rights zones) actually ruled by the Muslim (Sharia) law or by that of the underworld. ${ }^{6}$ The trauma was thus all the more violent as it brought to naught the idea of a democratically shared common territory: once again Jews found themselves isolated from the rest of society and delivered into the hands of murderers. Hence the community's need to honor the victim's memory but also to come together and try to understand.

Equally traumatic was the failure of authorities who were supposed to uphold the symbolic order. The trauma materialized a hallucinatory situation combining elements that I have already mentioned, namely the failure of all our republican institutions. Now it has become obvious that whenever national and international authorities give up on their functions ${ }^{7}$ and on the historical, legal, and anthropological landmarks-which articulate the lives of people as parts of a collective body, ensuring another mode of "living together," namely one which could be something more than an empty shell, an exorcist slogan, a paradigmatic instance of the desubstantializing of present reality on the part of right-thinking groups, something different from the "living together" whose

6 Cf. G. Bensoussan, ed., Une France soumise: les voix du refus (Paris: Albin Michel, 2017). 7 Cf. M. G. Wolkowicz, ed., États du Symbolique: Depuis L'Homme Moïse et la religion monothéiste, en passant par Freud, Rothko, Appelfeld... Droit, Loi, Psychanalyse (Paris: In Press, 2014). 
very expression suppresses the "third party" constitutive of "life in society," and might well turn out to mean "living together minus One" (that is, minus the Jew). Whenever those authorities give up on the ethics of truth, the demand for intellectual seriousness and responsible thought and action, one then falls into the raw Real and into foreclosure: denials are objectified, feelings of omnipotence spread, transgressions are rationalized, collective deliriums of filiation and self-generation get legitimized, all of which can only result in an explosion of acts of destruction and finally self-destruction. Thus, in the case of Sarah Halimi's murder, both police and the law gave in: the judge hastened to send the murderer to hospital, on the grounds that he did not have the mental ability to be interrogated; the very same justice had prosecuted Pascal Bruckner and later Georges Bensoussan for incitement to racial hatred, "Islamophobia" and "essentialization," but it instantly brushed aside the antisemitic motivation, be it only as an aggravating circumstance, in spite of the ritualized gesturing and chanting accompanying the extermination. The same French justice might perhaps have condemned Goebbels to ten years' imprisonment for criminal association in relation to a terrorist undertaking, as has just been the case with murderer Merah's elder brother and mentor. Similarly the media failed by not even reporting the murder as a news item. The cover-up of this cruel and significant crime by the press was remarkable. As George Steiner wrote about Shoah: "Words fail us, as we failed them." ralyzes thought, so does intellectual terrorism, and that dies hard. Press manipulation appears as one of the consequences of ideological pathologies. Misinformation by the media operates via semantic distortions, the fabrication of new mythologies, mirror reversals and role exchanges, tell-tale signs of pleasure and omnipotence as one comes to perceive the world exactly as one has hallucinated it, under one's control and in perfect conformity with one's representations: lazy thinking, a willed powerlessness (Nietzsche), a sense of narcissistic fullness as one swims with the compassionate tide while basking in selfaggrandizing projections as the very embodiment of rebellion, insubordination and indignation, substituting the idea for the truth in the name of good and universality. Hallucination as a product of conformity. All ideological, totalitarian languages (V. K. Klemperer, G.-A. Goldschmidt) begin by depriving language itself of its own memory, the narcissistic rule of ideology annihilating the locus of language, its political, neighborly features.

8 G. Steiner, “The Long Life of Metaphor,” Encounter (1987): 56. 


\section{The Mass Murder of a People by Individuals in Crowd Formation}

This was what caused so much distress and anger: the compulsion to repeat as evidenced by the crime and the identical denial of Islamist antisemitism ${ }^{9}$ participated in that feeling, as they turned the name Halimi into nobody's name, both victims having their lives taken away and their deaths obliterated, dissolved in senselessness and insanity, their identities massified; murdered for what they were, they were nonetheless eliminated as persons, since the genocidal intention was foreclosed. The word terrorism is used as a veil to avoid naming the crux of the matter, which is theological. "How can one persist in using only the word 'terrorist' to designate Islamist killers?" Were the Nazi killers mere "murderers" or "criminals," or were they murderers because they were Nazis? To evade the word "Islamist" is a way of relegating the killer's gesture to the category of a sensational news item. Not to do so amounts to integrating the guilt attending accusations of islamophobia, a process that is essential to the discursive strategy of Islamism. This strategy obeys a logic consisting in discrediting criticism. Why should it be racist to look closely into the Islamic matrix of Islamism? What if the persistent reduction of these crimes to psychiatric cases finally acted as a kind of Freudian slip, in that it points out the pathological dimension constitutive of ideology and its effects on individuals-psychically "en masse" whether they stand alone or in a crowd-while consciously aiming at dissociating the individual from the ideological group? Unless we are simply facing a misunderstanding of the workings of group psychology, group contamination, and hystericalparanoia identification in a crowd. There lies the (oh so terribly disquieting) banality of the mechanical acting out process. The perversion of language takes on a great variety of forms. How can one go on calling human bombs "suicide attacks"? What is the suicidal proportion in the act of a man who blows himself up in the midst of innocent civilians in order to make a maximum number of victims? In its obsessive concern with social causes, the compassionate ideology will never understand anything about Islamist terrorism so long as it continues to read it in terms of its own social, political, and psychological categories.

9 Cf. J. Tarnero, "'Le déni du réel ou le négationnisme du temps présent," in Le sujet face au réel, et dans la transmission, ed. M. G. Wolkowicz (Paris: In Press, 2017), 133. 


\section{The Anatomy of a Silence: A Ban on Thinking}

In immediate reaction, the same injunctions are brandished: "no amalgamation," “down with Islamophobia”; serving as exorcist slogans, these are used to induce "a ban on thinking." 10 One must mask the fact that Islam might be directly or indirectly related to violence, lest this give a jolt to the sacrosanct creed of "living together," fatal though this creed often turns out to be. And the fact that the price for it is paid by Jews is easily brushed aside, as experts after experts come forward to explain that "the first victims of terrorism are at bottom Muslims, the vast majority of moderate Muslims." Subjects are effaced, responsibilities dissolved, all sense of reality is obscured. The media orchestrate the propagation of the pleasures derived from repentance, absolution, and a perverse narcissistic guilt, the quest for love and self-sacrifice, which means above all the sacrifice of Jews to wolves. To think that the murderer is unbalanced, psychotic, or irresponsible ought to be regarded as more disquieting than comforting, and should seriously question the omnipresent power of the ideology influencing, contaminating and arming these atomized or agglutinated individuals. As a matter of fact the lone wolves entered Paris in July 2015, during an afternoon marked by a pro-Palestinian Islamo-leftist-Nazi demonstration comprising supporters of Hamas, Islamic Jihad, Palestinian Fatah, the Muslim Brotherhood, members of the ultra-left, elected representatives of the Greens, and far-right activists. As the march degenerated, a howling crowd rushed toward two near-by synagogues (in the rue des Tournelles and rue de la Roquette) intent on destruction-a pogrom-like violence reminiscent of what took place in Sarcelles, in Europe before World War II, as well as in Arab countries, sending 900,000 Jews into exile. From lone wolves to hordes of wolves.

Some people imagine that they are more objective because they embrace the subjectivity of others.

Eliana Amado Lévy-Valensi

10 Even if ten Islamist terrorist attacks were to happen a day, the media coverage would still be unchanged. The same questions would be asked again and again: did the terrorist attack have any connection with the Islamist State? What could account for an ordinary citizen, notwithstanding some criminal acts, to take this action? Are the terrorists "wretched loners" resorting to "low cost terrorism," a new concept which appeared after the Barcelona attack in the summer of 2017? Have they become more radicalized and how? Daesch terrorist ideology is nevertheless blamed for urging Muslims to commit barbaric crime, following a contagious momentum typical of crowd psychology, dramatically featuring the Arab crowd. Pacifist and absolving rituals display candles and teddy bears expressing forgiveness: "they won't have my hatred," "we'll go on sitting outside cafés," "why don’t they love us ?" 


\section{"Hallucinatory" is indeed an Apt Description of the Name Halimi, Turned into Nobody's Name}

By systematically reducing such ritualized genocidal murders to "border-line" acts, one exonerates the criminals from any affiliation to a human group and any genealogy of thought, as though they had lost their minds, committing senseless (?) acts; turning these crimes into non-events instead of seeing them as acting out an introjected discourse of which the subject himself as the object (?) contributes to turning the repetition of the name Halimi into a travesty of belonging, the simulacrum of a name, an Islamo-Nazi caricature of Jewish homonymy, a word exterminating language and its memory, exterminating the singularizing, historicizing, and subjectivizing distinctiveness of Jewish names: the name Halimi, like the Sarahs and Israels endlessly inscribed on the suitcases taken from deported Jews on their arrival in the Nazi extermination camps as shown in Claude Lanzmann's movie Shoah, ${ }^{11}$ became nobody's name. The Nazi parody of the Jewish name has been analyzed by Éric Marty. Negationism and revisionism are consubstantial with antisemitism and its genocidal project, murder. ${ }^{12}$ The Nazi extermination of the Jews also appears through the parodic homonymy whose principle is an extension of the mimetic principle to the point where mimetism itself becomes an extermination, an extenuation of all names. This parody of the principle of belonging appears as a morbid inversion, since the systematic use of "Israel" and "Sarah" actually turns them into synonyms for "nobody"; the Nazi operation on the names literally reverses the Jewish endeavor, which implies that the sacrificial process, to which we bear witness, is achieved through an effacing of subjectivity. Beyond the psychic and intellectual archaism of Jew-hatred, of this murderous drive acted upon in an increasingly mimetic and banal manner, in this unconscious generic reduplication of the name Halimi, from Ilan to Sarah, both tortured, savagely slaughtered, the bodies dumped by the side of railroad tracks or thrown out of the window like mere rags, schmattes, after having explicitly been subjected to stereotyped anti-Jewish ideological discourse without any place, any meaning being ascribed to them.

11 Cf. É. Marty, “"L'Échange inégal - Sur Guilad Shalit," in États du Symbolique: Depuis L'Homme Moïse et la religion monothéiste, en passant par Freud, Rothko, Appelfeld... Droit, Loi, Psychanalyse, ed. M. G. Wolkowicz (Paris: In Press, 2014), 83.

12 Cf. C. Lanzmann, Shoah, film, 9:00:00 (New Yorker Films, 1985), and the discussion by É. Marty, “'Shoah': Généalogie d'un nom, histoire d'une negation," in Présence de la Shoah et d'Israël dans la pensée contemporaine: Nom sacré / Nom maudit, ed. M. G. Wolkowicz (Paris: In Press, 2014), 107-22. 
All of a sudden names, instead of heralding a presence, produce nothing but absence and become the very names of extermination. Destruction ensures that no name can name any longer. The denial of the antisemitic act implies the obliteration of Jews in their factual, existential legitimacy, both singular and collective, but also the parallel obsession of their fantasized omnipresence, parasemitism.

"The final solution" was indeed what European culture gave birth to, as the end-product of a genealogy of thought and of a desire to destroy symbolic landmarks-consubstantial as these are to the question of being, to being as question. The paradigm of dehumanizing systems involves the use of words that enact a perpetual lie, the un-naming of people. "The final solution," the radical nature of mass murder implied that both words and the dead could never be sufficiently extinct, hence the absence of gravesites testifying to the survival of a human being in another human being. Language itself, which finds itself affected, as if it were dispossessed of its own memory and thus excluded from the epos of what is memorable. No word in the language escaped the perverse operation of lies. This was the core of the dehumanizing process, the loss of all likeness, of any possibility of similarity in difference. What we call "human" depends on the recognition of appearances making it possible to think in terms of a resemblance. In the experience of extermination humanity was doomed to dissimilarity. The undoing of a human ${ }^{13}$ means that appearances that used to permit recognition are undone. As Jean Améry put it, "Men were dying everywhere but the figure of death had vanished."14

\section{"Though this Be Madness, Yet There is Method in It"15}

The death camp at Belzec illustrated from the very beginning the Nazi determination to erase all traces of the destruction of the European Jews: ${ }^{16}$ bodies, names, and places had to be obliterated. Negationism was not solely a consequence of the crime, or even conditioned by fear of a possible judgement but was fundamentally its ultimate purpose. It did not only concern the reality and planned character of extermination, but it lay at the very basis of the

13 Cf. P. Levi, If this was a Man, trans. S. Woolf (London: Orion, 1959).

14 J. Améry, Par-delà le crime et le châtiment: Essai pour surmonter l'insurmontable (Arles: Actes Sud, 1995), quoted in Présence de la Shoah et d'Israël dans la pensée contemporaine: Nom sacré / Nom maudit, ed. M. G. Wolkowicz (Paris: In Press, 2014), 14. Translation by the author of this article.

15 W. Shakespeare, Hamlet, II, 2.

16 Cf. R. Hilberg, The Destruction of the European Jews (Chicago: Quadrangle, 1961). 
Nazis' delirious concerning origins and filiation. Obliterating the traces of the mass murder and its reality meant obliterating the Jews, effacing the very existence of the Jewish people from the history of humankind, annihilating any priority. ${ }^{17}$ Nothing short of this obliteration could realize the Nazi fantasy of embodying origin to all eternity, which entailed the supersession of the envied chosen people in order to come into possession of the symbolic treasure, the imaginary fullness of "being" only conceivable metonymically, in terms of "having." The same goes for Islamism, the politico-religious doctrine of Islam, which denies the historicity of the present order of things and refuses any event which doesn't fit the perfect reproduction of the same, an established narcissistic filiation, an identical transmission running counter to the idea of a people, whose legislator would stand as a guarantor for an unconscious whose law is supported. To graft itself onto this people, the Jewish people, onto the existing other, negated in its Jewishness as well as in its own infinite otherness, to spread the message while crushing the people appropriating the Jewish signifier in order to expel the Jew from the locus of his being, to place him essentially "outside the world" implies a disappearance; only thus will substitution be made possible; hence the necessity for extermination, the obliteration of all traces of the crime, of the other people's existence and of one's indebtedness. A reliable inter-subjective space is necessary for each and every one to feel part of the same species, the same humanity, part of a common world where one may have differences of opinion, come into conflict, and recognize the other in one's opponents, failing which one falls into the real and radical violence, archaic forms of destruction and self-destruction. It is human as bearing the question of existence, of the bonds uniting language, sexuality and the law which was exterminated. Indeed the collapse of the symbolic heralds the Real, which has to be put into words so that one may hope to be free from deadly drives and the compulsion to repeat.

17 Cf. M. G. Wolkowicz, Les Figures de la cruauté, entre civilisation et barbarie (Paris: In Press, 2016). 


\section{The Psychopathology of Anti-Judaism: The Transmission of Hatred and the Hatred of Transmission}

\section{A Truly Significant Symptom, in That it Was the Product of Repetition}

As his neighbor was a Jewish woman, the murderer projected onto her all the introjected stereotypes of the discourse and representations prevailing in his cultural environment, owing to which he could believe without any ambiguity or qualm of thought that she was in possession of all, either personally or through the solidarity of her community-all the power of being, of possessing the all, which prevented him from being and which was the very source of his own essential deficiencies. Which raises questions concerning both thought and action. What exactly is an antisemitic act? What is a subject? How does a subject construct itself as a political, collective subject? How does his relationship with reality, a moral conscience, get constructed? Acting out takes place when an individual has become an object but does not know what he is the object of, what he is activated by. He then acts as the object of a discourse that circulates in society, just like that, and that drives him to act without his having to refer to it, a dominant discourse that acts through him or makes him act (out); he may occasionally refer to it, but only as an after-effect; while he is acting he is the embodiment of a collective, latent discourse, which is not even explicit, nor is it only explicit in some areas of the collective space. ${ }^{18}$ "Where I am the object (of a discourse), I do not think," such is Jean-Pierre Winter's definition of the acting out. But acts of this kind are not insane, or exclusively insane, gestures; they are the products of another mental and cultural world.

The function of psychiatric experts is to assess the mental state of a criminal at the time the act was committed and consequently his penal responsibility. A particularly competent expert, Dr. Daniel Zagury, who was commissioned to examine Sarah Halimi's killer, concluded on an acutely delirious act, not without mentioning the presence of an antisemitic substratum. From a different angle I will submit that this act can be understood as a manifestation, conscious or unconscious, in the dynamics of a psychopathological structure in which antisemitic hatred is a symptom borne and transmitted by an introjected collective psy-

18 Cf. J.-P. Winter, “”Antijudaïsme et barbarie,” in Le sujet face au réel, et dans la transmission, ed. M. G. Wolkowicz (Paris: In Press, 2017), 649. 
che that is its real basis. Everywhere the same ideology, everywhere the same barbarity. All totalitarianisms have antisemitism in common. As if terrorists were not all, and always, psychopaths. As if the Nazi thugs of the 1920s and 1930s, Hitler's storm-troopers chasing their enemies and the SS ruffians in charge of the ideological instruction of the German masses had ever been anything else than more or less high-ranking psychopathic brutes. The question of the "lone wolf" pertains to the uberisation of a small-time terrorism, but one that is psychically en masse. Our society is discovering today that it must once again fight the fanaticized mortal enemies of liberal modernity, in whom one sees a meeting point between pathology-the megalomaniac fascination exerted by violence and the attractions of terrorism-and an ideology in which the pathology itself originates; these people place themselves above or outside all the prohibitions at the basis of civilization. What if Islamism were the expression of the same collective delirium of filiation, of an archaic envy, an ego splitting and a massive, obsessive projection of a shame attempting to dissolve itself in a form of hatred seeking to legitimize itself by finding a projectively persecuting, omnipotent and omnipresent object, a perverse-apathetic mass paranoia?

\section{The Man Moses and the Monotheistic Religion: Freud simultaneously Interrogates the "Character" of a People and what Predisposes the Other to Antisemitic Hatred, Characterized by a Hatred of the Name}

Today the theory of substitution, part of a trilogy comprising a theology of contempt and a strategy of defilement, also operates by proxy, as Europeans have endowed another people with symbolic attributes, substituting it for the Jewish people and Israel: indeed the "Palestinian people" has now become the new people, both relic and fetish, established as the original people. ${ }^{19}$

An equally staggering fact is the coincidence of the elaborate denial of reality and meaning where anti-Jewish terrorism is concerned, and the posturing and

19 What is at stake to ensure the present and out of desire and mimetic identification, is the theft of history, ancestors, signifiers, of what would constitute a whole held only by the People of Israel, which all Jews embody and have within themselves, and which would secure an existential and identity fulfilment, being almighty in its absolute and diabolic knowledge, requiring so as to make it one's own and keep alive the fantasy of self-begetting and self-essentializing, to obliterate it in order to take its place and to wipe it out from history, which will be hardly achieved without perpetrating endless destructions-and self-destruction. Such a human group will never become a people. 
resolutions of international institutions such as UNO and UNESCO-in which history gets voted upon by solid majorities and power politics instead of being studied and taught, just as right is the result of blackmail rather than a reference to the law. In this way, all extant Jewishness vanishes as the Jewish Name is dissolved and the history of the Jewish people is negated simultaneously with its links with its place, language, signifiers, figures and names, its historical, spiritual and psychic locus, its presence and constructions, both visible and invisible, as Freud has demonstrated when assessing the Jewish contribution to the foundations of civilization (precisely with a law at the center and through specific modes of identification and transmission), ${ }^{20}$ and subsequently to the cultures of the various countries in which Jews had been accepted.

\section{The Invention of the Jewish People, far from Being a Proof of (its) Non-existence, definitely Testifies to the Radical Singularity of its own Existence}

How may one conceive today what it is precisely that knots people together into a people, and what is it that makes a group regress to a mob-like state? How might one define the internal links of a people, its common fund, its cultural superego, and its historical truth?

Should this be conceived in terms of the question of the father and of transmission as an endless questioning, or conversely as a quest for immediate perception and satisfaction, for compulsive, boundless enjoyment?

What kind of signifying articulation can be sought between the individual and the community, between the community and the human species, what kind of identification can one opt for: one conceived as a form of internalizing process refusing idolization and constantly open to conflict, an identity forever in the process of becoming, always under construction as a plurality, as multiple possibilities of identity? Or one conceived as a cannibalistic incorporation, in this case a mimetic identity, a mortified identity seeking an embodiment in hatred?

20 All that would be needed, according to our official Pol Pot supporter, the philosopher Alain Badiou, is to dilute the noun "Jew" into the mythic universality of the generic, the unspecified, the conflation of all distinctions to solve the Jewish question and antisemitism, the soft final solution consisting in dilution of the noun "Jew." 
A people builds itself up by transferring on transmission, ${ }^{21}$ the transmission of transmission that enables the younger generations to become part of it by assuming a mutual transmission, the possibility thus opened to acquire and transform their heritage, to question it, and to recreate it before transmission.

Any living identity is an in-between. What matters therefore is to trace the genealogies of thought, and to examine the reasons why and the modes in which a culture may produce in the course of its history a moment of acute strain, a regression toward a mob-like state in which "progress can ally itself with barbarity."

Freud has shown that a people can be analyzed just as individuals can. To him violence has to do with an impossible mourning process on the part of the masses. In Group Psychology and the Analysis of the Ego, Freud asks himself the following question: how is it that a mass of people "acquires the capacity to influence the psychic life of the individual so decisively?" And what does this psychic alteration consist in?

In what ways does the psychic agglutination of individuals endow a dominant totalitarian ideology with the fullness of a collective narcissism so that each separate individual becomes mimetically identified through the idealization of a leader or of a totalizing cause, collective submission and idealization then coinciding with the community's compulsion to project onto a common scapegoat (whether internal or external) an eternal guilt and a full responsibility for every deficiency, failure, and frustration?

The enigmatic phenomenon of hypnosis ${ }^{22}$ brings to mind this image of a state in which the mass-ego appears as self-fascinated by its own non-fragmentable totality, sunk in blindness or sleep: "I am all in each," an individual caught in the crowd's group-narcissism and lack of differentiation as well as in love for one's leader and brothers. Being-in a multitude induces a state in which one can see and listen without hearing. All personal initiative is cancelled: "the hypnotist has taken the place of the ego-ideal (...) the hypnotic relation is the devotion of someone in love to an unlimited degree but with sexual satisfaction excluded." But as a matter of the fact that "precisely those sexual impulsions that are inhibited in their aims which achieve such lasting ties between people" 23 as eroticized violence in conjunction with the narcissistic passion for power contributes to turning the death instinct into a destructive drive. Whatever the slogan they

21 Cf. J.-P. Winter, Transmettre (ou pas) (Paris: Albin Michel, 2012).

22 F. Pierre, "'Hypnose, transfert et suggestion: Contribution à une métapsychologie du transfert et du contre-transfert," in Crise et contre-transfert (Paris: PUF, 1992), 97.

23 Freud, Group Psychology, 115. 
chant, the masses stage a cohesive and resolutive globalization of the world, through stereotypes and mimetic thinking (faith in this instance being on the side of submission). Could the fascist masses' need for fascination be related to such a death drive, an attraction toward murder and destruction? Freud tends to view things this way when he says that "man is basically a horde animal, an individual creature in a horde led by a chief." ${ }^{24}$ In a crowd heterogeneity yields to homogeneity, the singular makes way for the same. As part of a crowd the subject experiences a sense of power that can lift the repression of drives that he might not have obeyed otherwise. ${ }^{25}$ This is where, as Freud sees it, the subject's responsibility comes into question.

The mythical universality, the overwhelming mother figure, and the fraternal terrorist mass constantly work toward a desubstantializing of reality, by confusing the human, the crowd and the divine; meanwhile the project is indeed the wiping out of the symbolic order, "the human no-condition" as Emmanuel Levinas ${ }^{26}$ called it, against "the ethical obligation" in which the rules of speech are articulated, and in which one recognizes Freud's Oedipus complex limiting pleasure by the prohibition of incest and murder and cutting into the narcissistic omnipotence of the Other-wounding thereby that of the subject. ${ }^{27}$ And when the tyrannical paternal imago, a caricature masking an archaic all-powerful undifferentiated maternal figure, cracks up and crumbles, then the time is ripe for the fratricide that the homosexual coalition against the so-called Satan tried to avoid.

\section{Ibid., 121.}

25 Cf. G. Le Bon, The Crowd: A Study of the Popular Mind (Auckland: The Floating Press, 2009).

26 Cf. E. Lévinas, Totalité et Infini: Essai sur l'extériorité (Paris: Hachette, 1991).

27 Men substitute their ideal ego to this common object and identify to each other. The ideological discourse held by the leader, or its equivalent, directly reaches the listeners' unconscious, which doesn't acknowledge the process of negation or contradiction and which is beyond any form of temporality or space and in the end anything is possible. It is a discourse about love and the conflation of differentiations, about the impossible, to "little men" (W. Reich). At last a bright future to come (the 1,000 years of the Third Reich and paradise with 1,000 virgins). Such a discourse promises redemption to all and the possibility for individuals to act out their destructive impulses related to narcissist and supreme pleasure against the group who has led them to this state. Then collectiveness changes into an obscure mass and individuality into inconsistent particles seeing bondage in the quest of the self towards the ideal. The foreclosure of the name of the father, the disqualified fathers, worth noticing in criminals' and terrorists' families, the apparently omnipresent mother is bound to go toward spurious fathers-dictators, fanatic imams, asking for human sacrifices, for a fundamentalist cause, consubstantial to the society of brothers of the primitive horde, and is actually often related to brotherly configurations, carrying weapons and embodied by "martyrs" (e.g., the Muslim Brothers, the Coulibaly brothers, or the Mehra brothers). 
What is it that turns men into warriors or murderers? What is it that turns people into a group or a mass? Massenpsychologie is never far from Hassenpsychologie, which is often part of it. The transmission of hatred, intent on extermination, fundamentally partakes of a feeling of identity-based integrity and expresses a hatred of transmission. War has been replaced by mass murder; if war ceases to be conceivable in terms of conflict, the resulting dead are dissolved into a mass, which is tantamount to replacing death with disappearance. The Nazis as well as serial killers and genocidal Islamist fanatics enjoy the omnipotence resulting from their indifference to what is human and psychological, to the other, which they have reified, objectified, obliterated, reduced to nothing or rubbish, just as they enjoy their belief in an absence of limits. In this light "the group appears to us as a revival of the primal horde," 28 an No crowd can resist the temptation of doing harm gleefully.

\section{The Freudian Description of the Process of Becoming Man}

Might one consider what we call by the name of "psychic life" (what we call "psyche") is precisely the essential human appearance (?), which makes for our recognition of everyday humanity, and ensures the subjectivity of an inanimate being?

According to Freud, one may consider that the function of culture, which imposes sacrifices upon its subjects in an ambivalent conflict through a form of libidinal and narcissistic renunciation, is to intricate the principles of pleasure and reality through the recognition of processes of historization and subjectivation, in contradistinction with group psychology, which is devoid of any desire for the truth, without memory or language, and permits the untrammelled instinctual satisfaction sustaining the sense of an identity-based narcissistic omnipotence and plenitude, at its highest in the instinct for mastery, cruelty, and the sense of power over the world through the destruction, the dehumanization of the Other as a different-similar. The "love of certainties" and the temptation of immortality being present in the hypnotic suggestion of the masses, it is indeed the play of identifications, whereby humanity partakes simultaneously of resemblance and appearance, which is annihilated, placed alongside with incorporation and disappearance rather than on the side of loss and mourning.

28 Ibid., 123. 


\section{What Turns a People into a People?}

No people exists ex nihilo, as an essentialized entity embodying origin; on the other hand, it can and indeed must build itself in history, by appropriating a heritage, a plurality of filiations in a common project that is its own in coexistence with others, such a project assuming indebtedness, gratitude and free will, existing in constant self-renewal, disengaging itself from all projective temptations, ${ }^{29}$ from a culture of resentment and excuse, that ideological poison continuously and steadily discharged in public opinion. All of which tends to literally justify aggressive acts and helps to make it impossible to assess the situation in terms that are truly ethical, civilized, and political, leaving it archaically fixated in an endless state of war endlessly fueled by ethno-religious passions working against the recognition of historical facts and perpetually projecting one single idea onto the universal culprit marked out by an unbearable fantasy of distinction: the idea that one people might in essence have privileged access to "being," thereby preventing others from "having" the place he occupies in the eyes of those who resent his existence, whether this place be real, symbolic, or imaginary. $^{30}$

The Jew therefore may be envied even on the grounds of his misfortune, of Auschwitz as a symbol, projectively imagined as if he once more was possessed of All because of that-ultimately what he is envied for is his capacity to face the flaw and to assume a transmission of difference (as opposed to the same), a transmission that is constantly twisted, shifted, recognizing that the notion of identity is a delusion and renouncing a purely narcissistic transmission.

Thus the strength of the Jewish people does not exclusively lie in its concern for ethics, the work of guilt, and the internalization of the superego, but in the fact that its transferences, be they negative or positive, are directed toward transmission and not toward such or such a group, contrary to antisemites, who need the disappearance or obliteration of another group in order to exist, to be, to fantasize, to hope, to be happy. In order to survive the Jew does not require the obliteration of any other people.

29 Rather than feeling mortified and assuming a cynical and victim posture, which only strengthens the feeling of humiliation and projective identification and destruction to the point of using one's own children as human shields or human bombs. The first president of Algeria, Ben Bella, a country that has become independent and totalitarian from the start admitted that his people "could only be only if the other wasn't."

30 Perverse guilt can release either its hatred toward some (the Jews as a people) or its contempt toward others (identitary Islam). 
Antisemitism is the product of bankrupt identities asserting their fullness in the face of the flaws unmistakably reflected in their history.

The underlying paradox of antisemites' position is that while they are intent on making the Jew pay the heaviest price possible, they necessarily posit the hypothesis that what they want to eradicate is superior to them, so that as a matter of fact they condemn themselves to a pathetic and bitter satisfaction; they grant the Jew an infinite credit. Could it be that an identity-based hatred and a mortified sense of identity-both of which being expressions of an intolerable existential flaw and repeatedly seeking embodiment in an idealizing, totalizing and selfpurifying cause-find a meeting point in anti-Judaism, a meeting point for yearnings after a narcissistic absence of limits (unlimited then meaning "minus One") precisely in that blind spot of envy and demonization, could it be that parricidal filiations converge upon the intolerable "paternal" heritage-an object of fundamental ambivalence? In such a transference Jews come to be identified with everything that escapes us in our fate-the unconscious, the Real.

"Modern man's tragedy is not that the meaning of life escapes him, but that this worries bothers him less and less."

Václav Havel

\section{The Opium of Intellectuals}

The news is full of staggering examples of denials of reality, on the part of certain members of the French intelligentsia, past masters in the art of ideological negation: clinging as they do to an indiscriminate passion for great causes, and particularly fond of prismatic categories of thought, they have repeatedly shown themselves submissively attracted to various totalitarian ideologies annihilating the subject, mimetically actualizing themselves in the codes and rhetoric of the doxa prevailing in the world of media and politics, embodied in right-thinking conformity: from Nazism to Islamism, via Stalin and Pol Pot this doxa has tended to shield reality from investigation and criticism. As in the 1920s and 1930s, today's massive pacificism appears as an enigma that marches in the company, and in support of, those who slave-drive and kill en masse. One wonders whether a world undergoing a crisis involving identity and limits is not attempting to transfer its guilt and thus fabricate for itself a form of innocence as well as the assurance of its own salvation by perpetually, endlessly projecting (for itself) the distorted spectacle of Israel's "sin" and "inhumanity," as displayed in a continuous loop on the media screens, contrary to the very real and massive barbaric 
Islamist atrocities. As Bruckner puts it, "Repentance creates people who apologize for ancient crimes in order to exonerate themselves for present crimes."31

What lies at the basis of the ideological denial of reality? Its horizon of illusion and negation? Where does its force of conviction come from? A clinical study of contemporariness cannot fail to observe a genealogy of submissive thinking and of totalitarian thinking. Arthur Koestler, George Orwell, Simon Leys, Raymond Aron, and Albert Camus in L'Homme révolté (The Rebel: An Essay on Man in Revolt) had been the first to understand that communism implied the same hatred of freedom as fascism, while other intellectuals, blindly and delightedly deemed it just because of its theoretical foundations. To hell with freedom and the truth. A number of them in France have had a persistent and paradoxical history in terms of the fascinated or indulgent relationships they have entertained with totalitarian, not to say genocidal regimes. The media, ideological conformity, the humanities, and social sciences all seem to dramatize and trivialize, to fatalize and rationalize violence, legitimizing it by actively participating in the enjoyment of its own staging in a fantasy of perverse narcissistic mastery best illustrated by its capacity to confuse events. As Mohammed Merah's killer profile disturbed established patterns, nobody paid any attention to what he was saying. In the eyes of ideologues, black is white, hate is love, and antisemitism reduces itself to inter-community tensions. Pascal Bruckner examines the ways in which the hatred directed against the West always entails a hatred of the law and freedom, and after the murderous attacks on Charlie Hebdo and the Jewish supermarket Hypercacher, the temptation to yield ground to fundamentalists was already strong on all sides. One of postmodernism's assumptions is that the West is guilty as a matter of principle, while all non-Westerners are innocent; morality and academic knowledge are instrumentalized so as to impose a ban on any other perspective. One rakes up the history of the West to provide elements likely to feed the denial of reality and destructiveness, complicity and submission? As Philippe Val ${ }^{32}$ writes, "Not to report things is to collaborate with the worst of them." Why this antisemitic passion? What is it that persistently causes nations to unite "preachers of hate and preachers of shame" 33 and to refuse for centuries to acknowledge their moral, intellectual and symbolic indebtedness to Judaism and the Jews, produc-

31 Cf. P. Bruckner, The Tyranny of Guilt: An Essay on Western Masochism (Princeton: Princeton University Press, 2010), 98.

32 Cf. P. Val, "'Le Sujet face au réel - Cris et chuchotements," in Le sujet face au réel, et dans la transmission, ed. M. G. Wolkowicz (Paris: In Press, 2017), 123.

33 P. Bruckner, Le Sanglot de l'homme blanc: Tiers-Monde, culpabilité, haine de soi (Paris: Seuil, 1983), 76. 
ing Europe's obsessive desire to efface it (... and them) and a hatred so blinding that it leads to murder and collapse? Ideology simultaneously offers a solution to narcissism for its hatred of otherness, and a solution to love for its hatred of rivalry, hate being a form of identity-based self-assertion and participating in a united front against transmission, shame finding in it the monstrous end of its expiation; if we follow Eric Marty's analysis, we may consider that the locus of Judeophobia is paradigmatically that which legitimizes hatred and the meeting point of mimetic ideas, as if once again hate and shame themselves became an origin, in the absence of any origin. ${ }^{34}$

We have recently felt the evil wind of the lawsuit brought against the historian Georges Bensoussan. "Indicting a metaphor does not exculpate reality" (Jacques Tarnéro): "Since when does the rejection of a religion or an ideology express a racist attitude? What ideological denial forbids to see reality, the inversion of which lies at the heart of A. Finkielkraut's testimony at the trial. Finkielkraut questions this refusal to see what one's eyes can see. If one refuses to see reality and if one indicts those who attempt to reflect upon it, there's no way we can hope to escape social divisions and the growth of hatred.

Still, the doxa holds that the only racist threat in France comes from Islamophobia. According to Bruckner, ${ }^{35}$ everywhere race struggle seems to replace class struggle, as Raymond Aron feared sixty years ago. The experience of totalitarian regimes has taught us that languages, too, can develop illnesses which may corrupt them. "Islamophobia" is one of those toxic words that confuses and denatures the whole vocabulary, which then becomes a new instrument in the extension of a fundamentalism proceeding with its face masked, draped in the victim's apparel and armed with a twofold ambition. The first is to silence Westerners, who Bruckner claims to be guilty of three capital sins: religious freedom, freedom of thought, equality between men and women. But above all, according to Bruckner, the aim is to forge an internal police tool in order to control reformist or liberal Muslims. Frédéric Encel $^{36}$ has shown the inversion of values, which results in antiracism being harnessed by obscurantism and discrimination against women, while UNO is being transformed into an instrument of international regression. The European way of war is a matter of minutes of silence, words of "peace and love," funeral ceremonies, flowers and candles, and a cow-

34 Cf. M. G. Wolkowicz, “"L’analyste à la masse. Passer de la haine à la guerre: ainsi pourrait se dire l'œuvre d'une analyse," in La psychologie de masse, aujourd'hui, ed. M. G. Wolkowicz et al. (Paris: Rosiers, 2012), 83.

35 P. Bruckner, Un racisme imaginaire: La querelle de l'islamophobie (Paris, Grasset, 2017).

36 Cf. F. Encel, "Daesh et le nazisme, quelques caractéristiques communes," in Les Figures de la cruauté, entre civilisation et barbarie, ed. M. G. Wolkowicz (Paris: In Press, 2016), 413. 
ardly refusal to link the murderous terrorism in Israel with the terrorism operating in Europe. And in a kind of mirror effect we have the contagious suggestion of the activated mass formation together with the stunning, hypnotic, and paralyzing fascination exerted by the atrocities of primal hordes, in this case Islamist killers unspecified by the occidental medias, by the real of barbaric violence, of cruel murders, rapes, and beheadings, all of which seem to partake of a regression toward some reactualized primal scene, a pre-symbolic ritual reenacting reminiscences from an archaic past, from the time of human sacrifices. Has all reason been lost before this lifting of the fundamental repression?

And here is Europe, shameful, fearful, uneducated, ${ }^{37}$ in quest of a universal expiatory redemption, having got rid of the greater part of her Jewish population, yet not inoculated against her antisemitism. As a representative of a paternal order, the Jew seems to act as a permanent reminder of the fundamental character of sex and generation differences, as has been demonstrated by Sophie Freud Loewenstein, Béla Grunberger, and Janine Chasseguet-Smirgel: all of them have pointed out the "avoidance of the Oedipus complex" in Christianity as well as among the 1968 "revolutionists." Can we consider that a Europe in a state of cannibalistic melancholy and in quest of redemption is trying to transfer her guilt and to fabricate for herself an innocence and the assurance of salvation? Judeophobia is the fear engendered in the anti-Jewish subject by his repressed own, which he then transfers onto the Jew, as the latter renews his refusal both of Christian grace and Islamic submission. In the ideology of the media, politics, and diplomacy, the Jew and Israel have to be treated as a mere parenthesis. Fourteen Jews have been killed in France and Belgium since 2006 because they were Jews. No amalgamation or silence will indefinitely hide these crude facts. What matters is to maintain the Jew "within the boundaries of Auschwitz" whenever he attempts to tear himself away from his status as expiatory victim bearing the stigma of original sin, and thus to demonize and Nazify him. ${ }^{38}$

37 Cf. S. Freud, Beyond The Pleasure Principle, trans. J. Strachey (London: The Hogarth Press \& The Institute of Psycho-Analysis, 1950). In a widely dechristianized society, the symptom of compulsive repetition in contemporary European antisemitism repeats the same structures, what has been suppressed is coming back all the more powerfully as it has been denied.

38 We are sorry for the exterminated Jews, we loathe the ordinary citizens of a nation, and thus antisemitism, following a perverse rhetoric, thrives and is shamelessly and immodestly allowed by the name of anti-Zionism (cf. V. Jankelevitch). The connection isn't made between proPalestine and Islamic terror, though the former has been the gateway to the latter. Politicians and media people are responsible for actually bringing in "the Israeli-Palestinian conflict" as an excuse to the necessarily "desperate" actions of the terrorists. During the war that opposed the State of Israel to Hamas and Islamic Jihad, anti-Israeli protests conflated the browns, the greens, and the reds that George Orwell used to call in the 30s, to characterize this ideological 
Denial is central to modern antisemitism. Anti-Jewish madness, whether expressed by Hamas or Goebbels, deserves to be analyzed for what it really is, and not in the roles it is made to play in the service of a hidden agenda. Transforming Jihad into a class war is tantamount to forgetting its cultural origin. If one wants to restore faces to the victims, we have to confront the reality of things. Today's antisemites proclaim themselves anti-system and anti-racist, while imputing to the Jews racism and the possession of the system; the Jew is no longer attacked as such, but one attacks the horrors of which he is presumed to be guilty.

We are thus drawn into paradoxical situations that are literally "maddening," literally "drive one crazy." We want the antisemitic nature of acts against Jews to be recognized by people whose culture has developed around negationist representations; in other words we want the Shoah to be recognized by people who simultaneously negate its existence and regret that the planned extermination was not fully carried out, or we want the Jewish character of the State of Israel to be recognized by people who deny it the right to exist. "What can object to the man who wants to slit my throat to earn his paradise?" Bruckner asks, quoting Voltaire, while the truth we do not want to hear is blatant: they hate us for what we are.

\section{Conclusion}

Still, the twentieth century should have taught intellectuals to be more humble. One cannot ignore an antisemitism that is one of the symptoms and maybe one of the sources-whether one wants it or not-of what Abdelwahab Meddeb calls "The Malady of Islam." Bruckner is concerned about the weakness of our democracies in the face of the "murderous jihadist madness" contaminating European countries. A great deal remains "unthought" in the way we approach terrorism, while Jihadists claim they are the only true Muslims. The ideological denial of that reality constitutes the other face of this disaster of thought, together with the compassionate pro-Palestinian obsession of part of the Left and the far Left, which has also bred the hatred of Jews; to present Israel as responsible for Arab misfortune is one of the great frauds of contemporary history. Everyone intones the mantra "avenge Palestinian children!" But what about Jewish children? Who spares a thought for them among the noble souls demonstrating? The killers were not the supposed promoters of Islamophobia, but real Islamist

mixture, "the fascists," and showed outraged pacifists and exterminatory Islamist bigots marching side by side. 
killers armed with Kalashnikovs: the confusion is at its height when the prime responsibility for Islamist hate crimes is ascribed to a reaction against the "Islamophobic climate" allegedly created and fostered by some intellectuals and writers categorized as members of a supposedly crypto-fascist sphere.

The fetishistic slogan "I am Charlie," "I am a cop," "I am a Jew," which inundated the demonstration is also a tell-tale sign of surrender, this time an inner surrender: if "I" am every victim, I am in fact no one, as I choose not to accept what I am, and not to face the attacker in order to win the fight. As regards the neutralization of the victims' identities, the Jews were a problem for commentators, since the general spirit of abdication cannot tolerate their breaking out of their roles as silent consenting victims, which would be the case if they were to decide to leave the country. It is only in their position as victims that Jews can be celebrated as sacred symbols of the Republic ("Whoever hurts a Jew hurts our Republic"), which is quite ominous in fact, since the sacred lies very close to the terrifying taboo, one feeding the other and potentially reversing itself into the other. The victims at the Bataclan were "innocent French people," conjuring up an echo of Raymond Barre's Freudian slip after the bombing of the Rue Copernic synagogue in 1980! Again and again, the day after November 13th, the same question was heard in every possible form: "But why us? Why France?" From now on, breaking the necessarily supposedly "neo-reactionary" fire detectors won't be enough, and the fire will not burn itself out, even at the cost of sacrificing Jews or at best alienating both the Jewish and Muslim communities, another perverse manner to deny the specific problems posed by Islam to the Republic, and by denying the exemplary integration of the Jews of France, and their particular implication to defend and enrich the Republic in all the fields.

The murder of Sarah Halimi was an apparently isolated act, but it was really the product of an ideological group activated by the hatred of Jews and entailing a collective hush up authorizing an identical repetition and negation. JeanJacques Moscovitz has shown how terror annihilates any form of desire on the part of potential victims, including the desire to kill: l'Enténèbrement, Darkness Visible, according a quote from Milton, already taken again on by William Golding in one of his novels, means the killing of death itself; for today's mass killers, negationism involves even the act of getting killed. It joins politics and psychoanalysis in terms of silencing/foreclosure. ISIS suggests that the murderers unconsciously identify themselves with the reality of origin as such. They are death itself, in a kind of "deathly incest" in which all bodies are intermingled: the killer enacts an apocalypse in which extermination is the means and aim of the end of the human world. As death came to be master of Germany, Nazism and Islamism destroy the origin to embody themselves in it totally and for- 
ever. As a source of a possible interpretation of their limits, the Jew, the Mensch, must be exterminated. And the same goes for the Yezidi, and other communities.

Perhaps antisemitism can best be understood as a chronic illness of Western politics, the latter finding itself incapable of confronting what has constituted it, or rather what its constitution began with and went beyond: a certain idea of a people and its law, the two-sided idea that is formed in the Geist of Geistigkeit. ${ }^{39}$

Sarah Halimi's murder was destructive of humanity. The function of judges is to state the law, and it is our duty as citizens in a democracy to state what we want and what we do not want, with regard to the freedom of ideologies that deny the laws and principles of our Republic, which terrorize and fashion minds in hate, and which promote murderous acts. One wonders whether Goebbels might not be condemned today by French justice, Nuremberg notwithstanding, for criminal association in relation to a terrorist undertaking.

Michel Gad Wolkowicz is psychoanalyst (APF) and was professor of psychopathology at the Paris-Sud Orsay University Hospital Group. He is president of the Association Internationale Schibboleth - Actualité de Freud (France) and of the Interdisciplinary Institute Schibboleth - Presence of Freud (Israel). He directed multiple symposia and collective interdisciplinary volumes focusing on psychoanalysis, history, law, philosophy, sciences, medicine, literature, cinema, analysis of speeches, media, and ideologies. His recent publications include La transmission en question(s) (2020), Si c'est Jérusalem (2019) and Le nouvel antisémitisme en France (2018).

\section{References}

Améry, Jean. Par-delà le crime et le châtiment: Essai pour surmonter l'insurmontable. Arles: Actes Sud, 1995.

Bensoussan, Georges, ed. Une France soumise: les voix du refus. Paris: Albin Michel, 2017. Bruckner, Pascal. "L'inversion de la dette. Antisémitisme et islamophobie." In Présence de la Shoah et d'Israël dans la pensée contemporaine: Nom sacré / Nom maudit, edited by Michel Gad Wolkowicz, 67-106. Paris: In Press, 2014.

Bruckner, Pascal. Un racisme imaginaire: La querelle de l'islamophobie. Paris: Grasset, 2017. Bruckner, Pascal. Le Sanglot de l'homme blanc: Tiers-Monde, culpabilité, haine de soi. Paris:

Seuil, 1983.

39 Cf. S. Freud, Moses and Monotheism, in vol. 23 of The Standard Edition of the Complete Psychological Works of Sigmund Freud, ed. J. Strachey (London: The Hogarth Press and the Institute of Psycho-analysis, 1964). 
Bruckner, Pascal. The Tyranny of Guilt: An Essay on Western Masochism. Princeton: Princeton University Press, 2010.

Encel, Frédéric. "Daesh et le nazisme, quelques caractéristiques communes." In Les Figures de la cruauté, entre civilisation et barbarie, edited by Michel Gad Wolkowicz. Paris: In Press, 2016.

Fédida, Pierre. "Hypnose, transfert et suggestion: Contribution à une métapsychologie du transfert et du contre-transfert." In Crise et contre-transfert, 67-110. Paris: PUF, 1992.

Freud, Sigmund. Beyond The Pleasure Principle. Translated by James Strachey. London: The Hogarth Press \& The Institute of Psycho-Analysis, 1950.

Freud, Sigmund. Group Psychology and The Analysis of The Ego. In vol. 18 of The Standard Edition of the Complete Psychological Works of Sigmund Freud, edited by James Strachey. London: The Hogarth Press and the Institute of Psycho-analysis, 1955.

Freud, Sigmund. The Loss of Reality in Neurosis and Psychosis. In vol. 19 of The Standard Edition of the Complete Psychological Works of Sigmund Freud, edited by James Strachey. London: The Hogarth Press and the Institute of Psycho-analysis, 1961.

Freud, Sigmund. Moses and Monotheism. In vol. 23 of The Standard Edition of the Complete Psychological Works of Sigmund Freud, edited by James Strachey. London: The Hogarth Press and the Institute of Psycho-analysis, 1964.

Freud, Sigmund. Totem and Taboo. In vol. 13 of The Standard Edition of the Complete Psychological Works of Sigmund Freud, edited by James Strachey. London: The Hogarth Press and the Institute of Psycho-analysis, 1955.

Hilberg, Raul. The Destruction of the European Jews. Chicago: Quadrangle, 1961.

Lanzmann, Claude. Shoah. Film, 9:00:00. New Yorker Films, 1985.

Le Bon, Gustave. The Crowd: A Study of the Popular Mind. Auckland: The Floating Press, 2009.

Lévinas, Emmanuel. Totalité et Infini: Essai sur l'extériorité. Paris: Hachette, 1991.

Marty, Éric. "L’Échange inégal - Sur Guilad Shalit." In États du Symbolique: Depuis L'Homme Moïse et la religion monothéiste, en passant par Freud, Rothko, Appelfeld... Droit, Loi, Psychanalyse, edited by Michel Gad Wolkowicz, 83-98. Paris: In Press, 2014.

Marty, Éric. “'Shoah': Généalogie d'un nom, histoire d'une négation." In Présence de la Shoah et d'Israël dans la pensée contemporaine: Nom sacré / Nom maudit, edited by Michel Gad Wolkowicz, 107-22. Paris: In Press, 2014.

Steiner, George. "The Long Life of Metaphor." Encounter (1987): 55-61.

Tarnero, Jacques. "Le déni du réel ou le négationnisme du temps présent." In Le sujet face au réel, et dans la transmission, edited by Michel Gad Wolkowicz. Paris: In Press, 2017.

Val, Philippe. "Le Sujet face au réel - Cris et chuchotements." In Le sujet face au réel, et dans la transmission, edited by Michel Gad Wolkowicz. Paris: In Press, 2017.

Winter, Jean-Pierre. “Antijudaïsme et barbarie." In Le sujet face au réel, et dans la transmission, edited by Michel Gad Wolkowicz. Paris: In Press, 2017.

Winter, Jean-Pierre. Transmettre (ou pas). Paris: Albin Michel, 2012.

Wolkowicz, Michel Gad. "L'analyste à la masse. Passer de la haine à la guerre: ainsi pourrait se dire l'œuvre d'une analyse." In La psychologie de masse, aujourd'hui, edited by Michel Gad Wolkowicz, Thibault Moreau, Alexis Nouss, and Gérard Rabinovitch, 83-172. Paris: Rosiers, 2012. 
Wolkowicz, Michel Gad, ed. États du Symbolique: Depuis L'Homme Moïse et la religion monothéiste, en passant par Freud, Rothko, Appelfeld... Droit, Loi, Psychanalyse. Paris: In Press, 2014.

Wolkowicz, Michel Gad. Les Figures de la cruauté, entre civilisation et barbarie. Paris: In Press, 2016.

Wolkowicz, Michel Gad, ed. Le sujet face au réel, et dans la transmission. Paris: In Press, 2017. 